We are grateful to Dr N A Barrington, consultant radiologist, and to Dr $M$ Holroyd, principal physicist, for their help in evaluating this case.

${ }^{1}$ McGehee WG, Rapaport SI, Hjort PF. Intravascular coagulation in fulminant meningococcaemia. Ann Intern Med 1967;67:250-60.

2 Tochen ML. Bone lesions in a child with meningococcal meningitis and disseminated intravascular coagulation. $\mathcal{F}$ Pediatr 1977;91:342-3.

${ }^{3}$ Robinow M, Johnson GF, Nanagas MT, Mesghali H. Bone lesions following meningococcaemia and disseminated intravascular coagulation. A recognizable skeletal dystrophy. Am $\mathcal{F}$ Dis Child 1983;137: 279-81.

- Beyer P, Hasselman JL, Sam-Amavih H, Stoebner P, Schneegans E. Coagulation intra-vasculaire disséminée s'accompagnant de troubles ischémiques des extrémités et de lésions osseuses multiples chez un petit nourrison atteint de septicémie. Pédiatrie 1972 ;27:423-32.

(Accepted 16 September 1983)

University Department of Therapeutics, Royal Hallamshire Hospital, Sheffield S10 2JF

JOHN S DUNCAN, MA, MRCP, registrar in medicine

LAWRENCE E RAMSAY, MB, FRCP, consultant physician

Correspondence to: Dr L E Ramsay.

\section{An abnormal collagen $\alpha$ chain containing cysteine in autosomal dominant osteogenesis imperfecta}

The brittle, osteoporotic bones that characterise osteogenesis imperfecta often mask more generalised changes in connective tissue. These may develop in the skin, which is often soft and hyperextensible, and the eyes, where the scleras are often blue owing to their reduced thickness. Umbilical and inguinal hernias, joint hypermobility, floppy mitral valves, blood vessel fragility, and poor dentition have also been noted. ${ }^{1}$ The disease is clinically variable; Sillence et al have classified four major subgroups based on mode of inheritance and disease severity, ${ }^{2}$ but each of these groups appears to be heterogeneous. The clinical variability and the diversity of the changes in connective tissue suggest a group of generalised molecular defects. Recently biochemical investigation of the disease has shown a number of abnormalities of collagen, the major structural protein of connective tissues. The recognition of these abnormalities is important for the clinical understanding of the disease and in assessing its potential for prenatal diagnosis. We report one form of osteogenesis imperfecta designated type I by Sillence that is characterised by an abnormal collagen $\alpha$ chain containing cysteine.

\section{Subjects, methods, and results}

Our patient was an 11 year old boy with normal teeth, blue scleras, and short stature who had suffered recurrent fractures and malhealing of his tibias. Paradoxically, at operation his bones were noted to be unusually hard despite their brittle nature. His mother was also short with a history of fractured small bones of the hand during childhood; his father and sister were clinically normal.

Cell cultures were established from skin and bone biopsy specimens, taken from the patient at surgery, and from skin biopsy specimens from both parents and the sister. The proteins synthesised by these cells were radioactively labelled by feeding with a medium (modified Eagle's medium Dulbecco) containing ${ }^{14} \mathrm{C}$-proline $(1 \mu \mathrm{Ci} / \mathrm{ml})$. Purified collagens were then examined by sodium dodecyl sulphate gel electrophoresis ${ }^{3}$ with delayed mercaptoethanol reduction to resolve type III collagen. ${ }^{4}$ Radioactive band were visualised by fluorography, ${ }^{5}$ and the $x$ ray plates canned in a densitometer.

The boy's clinical features were typical of mild Sillence type I osteogenesis imperfecta. Gel electrophoresis (figure) of the collagens synthesised by the patient's skin and bone cells and also by the mother's skin fibroblasts showed an unusual band $\left(\mathrm{X}^{\prime}\right)$ in addition to the normal $\alpha 1(\mathrm{I})$ and $\alpha 2(\mathrm{I})$ collagen chains. The $X^{\prime}$ band was seen in neither the father's nor the sister's skin fibroblast cultures nor in a number of control fibroblast lines. Without mercaptoethanol reduction $\mathrm{X}^{\prime}$ had a molecular weight approximately twice that of a normal collagen $a$ chain. After delayed mercaptoethanol reduction (figure) $\mathbf{X}^{\prime}$ disappeared to be replaced by another new band ( $\mathrm{X}^{\prime \prime}$ ) migrating slightly faster than the $\alpha$ (III) collagen chains. As mercaptoethanol breaks the disulphide bonds formed between cysteine residues of proteins we inferred that $X^{\prime \prime}$ contained a cysteine residue and that $X^{\prime}$ was its disulphide bonded dimer.

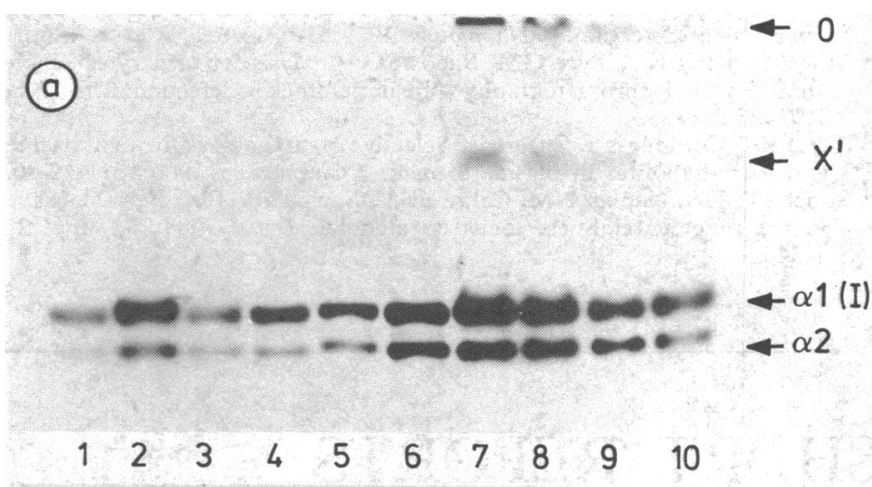

(b)

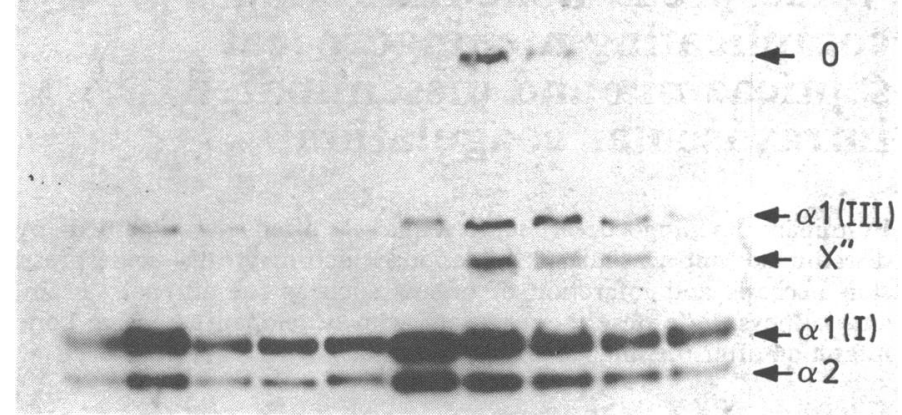

Sodium dodecyl sulphate polyacrylamide gel electrophoresis of radioactively labelled collagens isolated from cell cultures of controls $(1,2,3,4$, $5,6)$, patient's bone (7), patient's skin (8), mother's skin (9), and father's skin (10)

(a) without mercaptoethanol reduction

(b) with mercaptoethanol reduction after an initial period of electrophoresis. $O$ marks top of each gel.

\section{Comment}

Measurement of the various $\alpha$ chains by densitometry suggested that the $\alpha$ chains containing cysteine were associated in a triple helical molecule with a normal $\alpha 2$ chain. The predominant collagen in normal bone is type I collagen, which has a chain composition $\alpha 1(I)_{2} \alpha 2$. None of these chains contains a cysteine residue. Type III collagen, which is not a normal constituent of bone, has two cysteine residues in each chain and forms a disulphide bonded trimer containing three identical chains designated $\alpha 1\left(\mathbf{I I}_{3}\right) . \alpha 1$ (III) chains, however, have never been found to associate with $\alpha 2$ chains of type I collagen.

The new $X^{\prime \prime}$ chain was probably produced by a point mutation in the $\alpha 1(I)$ chain. This can arise from a single base change in the $\alpha 1$ (I) gene, for example, a substitution of cytosine, adenine, or guanine by thymine in the deoxyribonucleic acid would convert either an arginine, serine, or glycine residue to a cysteine residue in the protein.

This study provides another example of the biochemical diversity of osteogenesis imperfecta, which is becoming increasingly apparent in published reports, and suggests that the clinical classification of Sillence $e t a l^{2}$ will have to be modified to accommodate the biochemical findings. The heterogeneity of this and other inherited diseases of connective tissue is perhaps not surprising considering the large size of the collagen molecule (three chains of 1500 residues each compared with 146 residues of the $\beta$ globin chain) and the extremely large and complex nature of the collagen gene, which has as many as 50 non-coding regions dispersed in a $\mathbf{4 0}$ kilobase gene.

Our results also show the generalised nature of osteogenesis imperfecta, the abnormality being manifest in cells derived from both skin and bone. Conversely they suggest that inherited diseases of collagen may be studied successfully using readily accessible skin fibroblasts even though the disease may primarily affect internal organs. 
i McKusick VA. Mendelian inheritance in man. 5th ed. Johns Hopkins University Press, 1978.

${ }^{2}$ Sillence DO, Senn A, Danks DM. Genetic heterogeneity in osteogenesis imperfecta. F Med Genet 1979;16:101-16.

${ }^{3}$ Laemmli UK. Cleavage of structural proteins during the assembly of the head of bacteriophage T4. Nature 1970;227:680-5.

4 Sykes BC, Puddle B, Francis MJO, Smith R. The estimation of two collagens from human dermis by interrupted gel electrophoresis. Biochem Biophys Res Commun 1976;72:1472-80.

${ }^{6}$ Laskey RA, Mills AD. Quantitative film detection of ${ }^{3} \mathrm{H}$ and ${ }^{14} \mathrm{C}$ in polyacrylamide gels by fluorography. Eur $\mathcal{F}$ Biochem 1975;56:335-41.

(Accepted 23 September 1983)

Medical Research Council Clinical Research Centre, Harrow, Middlesex HA1 3UJ

A C NICHOLLS, BSC, PHD,

F M POPE, MD, FRCP,

Southlands Hospital, Shoreham by Sea, West Sussex

D CRAIG, MB, FRCS,

Correspondence to: Dr A C Nicholls.

\section{Detection of subclinical abortion by assay of pregnancy specific $\beta_{1}$ glycoprotein}

Detection of human chorionic gonadotrophin in blood or urine during the luteal phase led to the suggestion that many apparently infertile women may conceive but lose the pregnancy at the subsequent menstruation. ${ }^{1}$ Schwangerschaftsprotein 1 is another placental product whose presence in the circulation is at least as reliable as that of human chorionic gonadotrophin in indicating pregnancy. ${ }^{2}$ To see whether such occult pregnancy occurred we assayed Schwangerschaftsprotein 1 concentrations in one patient over seven successive menstrual cycles.

\section{Case report}

A 29 year old woman with nine years' unexplained infertility was treated with $100 \mathrm{mg}$ clomiphene citrate for five days at the start of her menstrual cycle, followed by 5000 IU human chorionic gonadotrophin 10-12 days later. She was instructed to have intercourse after the injection of human chorionic gonadotrophin, and on two occasions her husband's semen was artificially inseminated. Her basal body temperature was recorded daily, and blood samples were taken four to six times during the luteal phase for measurement of serum concentrations of oestradiol, progesterone, $\beta$ human chorionic gonadotrophin, and Schwangerschaftsprotein 1. During the fifth cycle a transient rise in concentration of Schwangerschaftsprotein 1 was noted just before menstruation, so in cycles 6 and 7 blood samples were taken daily from the time of injection of human chorionic gonadotrophin to menstruation. Concentrations of progesterone and oestradiol were measured by standard radioimmunoassay techniques using specific antisera. $\beta$ Human chorionic gonadotrophin concentration was measured by radioimmunoassay using a commercial kit (Serono). All concentrations higher than $10 \mathrm{IU} / 1$ were taken as positive. Schwangerschaftsprotein 1 concentrations were measured by enzyme immunoassay using a kit (Behringwerke), the lower limit of sensitivity of which is $0.3 \mu \mathrm{g} / \mathrm{l}$.

The first four cycles were normal ovulatory ones, in which progesterone concentrations found in conceptual cycles were reached, ${ }^{3}$ but concentrations of $\beta$ human chorionic gonadotrophin and Schwangerschaftsprotein 1 showed no evidence of conception. The table shows the results of assays in the last three cycles. Ovulation (day 0 ) was defined in terms of basal body temperature and change in steroid concentration. The rises in serum $\beta$ human chorionic gonadotrophin concentrations immediately after ovulation in these three cycles were caused by the injections of the hormone and cannot be taken as evidence of pregnancy. On day 27 of the fifth cycle a transient rise in Schwangerschaftsprotein 1 concentration was recorded. On day 24 of the sixth cycle high concentrations of $\beta$ human chorionic gonadotrophin and Schwangerschaftsprotein 1 were recorded, but Schwangerschaftsprotein 1 concentration was declining by day 27 . Bleeding began on day 28 , but a blood sample was not taken. In the seventh cycle concentrations indicating pregnancy were seen on day 27 , coinciding with the premenstrual fall in progesterone concentration. They were still present on day 30 , when a heavy period began. The high concentration of Schwangerschaftsprotein 1 persisted for the first two days of bleeding, but in view of the long half life of this protein ${ }^{4}$ this does not necessarily indicate that trophoblastic tissue persisted for that time.
Concentrations of placental proteins and hormones during cycles 5 to 7 with presumed subclinical abortion (clomiphene citrate given at start of each cycle)

\begin{tabular}{|c|c|c|c|c|c|}
\hline $\begin{array}{l}\text { Days from } \\
\text { menstruation }\end{array}$ & $\begin{array}{c}\text { Days } \\
\text { from } \\
\text { ovulation } \\
\text { (day 0) }\end{array}$ & $\begin{array}{c}\text { Oestradiol } \\
(\mathrm{nmol} / \mathrm{l})\end{array}$ & $\begin{array}{l}\text { Progesterone } \\
(\mathrm{nmol} / \mathrm{l})\end{array}$ & $\begin{array}{c}\beta \text { Human } \\
\text { chorionic } \\
\text { gonadotrophin } \\
(I U / 1)\end{array}$ & $\begin{array}{c}\text { Schwangerschafts- } \\
\text { protein } 1 \\
(\mu \mathrm{g} / \mathrm{l})\end{array}$ \\
\hline \multicolumn{6}{|c|}{ Fifth cycle } \\
\hline $\begin{array}{l}12^{*} \\
15 \\
19 \\
20 \\
21 \\
22 \\
25 \\
27\end{array}$ & $\begin{array}{l}-1 \\
+2 \\
+6 \\
+7 \\
+8 \\
+9 \\
+12 \\
+14\end{array}$ & $\begin{array}{l}2.46 \\
0.50 \\
1.16 \\
0.93 \\
1.04 \\
1.02 \\
0.94 \\
0.36\end{array}$ & $\begin{array}{r}1.95 \\
28.95 \\
>50.00 \\
>50.00 \\
>50.00 \\
>50.00 \\
30.75 \\
4.70\end{array}$ & $\begin{array}{r}3 \cdot 4 \\
40 \cdot 8 \\
10 \cdot 3 \\
5 \cdot 7 \\
4 \cdot 9 \\
5 \cdot 7 \\
3 \cdot 8\end{array}$ & $\begin{array}{l}<0.3 \\
<0.3 \\
<0.3 \\
<0.3 \\
<0.3 \\
<0.3 \\
<0.3 \\
0.64\end{array}$ \\
\hline \multicolumn{6}{|c|}{ Sixth cycle } \\
\hline $\begin{array}{l}13^{*} \\
14{ }^{\dagger} \\
15 \\
16 \\
17 \\
20 \\
21 \\
22 \\
23 \\
24 \\
27\end{array}$ & $\begin{array}{r} \\
+\quad 1 \\
+2 \\
+3 \\
+4 \\
+7 \\
+8 \\
+9 \\
+10 \\
+11 \\
+14\end{array}$ & $\begin{array}{l}3.44 \\
2.93 \\
0.86 \\
0.55 \\
1.22 \\
2.18 \\
1.94 \\
\\
2.03 \\
2.06 \\
0.43\end{array}$ & $\begin{array}{r}3.15 \\
12.65 \\
11.95 \\
42 \cdot 10 \\
48 \cdot 80 \\
>50.00 \\
>50.00 \\
\\
>50.00 \\
>50.00 \\
6.35\end{array}$ & $\begin{array}{r}19.5 \\
97.1 \\
57.0 \\
42.7 \\
32.5 \\
8.8 \\
9.3 \\
4.0 \\
2.0 \\
116.0 \\
144.0\end{array}$ & $\begin{aligned}<0.3 \\
<0.3 \\
<0.3 \\
<0.3 \\
<0.3 \\
<0.3 \\
<0.3 \\
<0.3 \\
<0.3 \\
\quad 1.28 \\
0.74\end{aligned}$ \\
\hline \multicolumn{6}{|c|}{ Seventh cycle } \\
\hline $\begin{array}{l}14^{*} \\
15 \\
16 \\
17 \\
18 \\
20 \\
21 \\
22 \\
23 \\
24 \\
25 \\
26 \\
27 \\
28 \\
29 \\
30 \ddagger \\
31 \\
32\end{array}$ & $\begin{array}{l}-1 \\
+0 \\
+1 \\
+2 \\
+3 \\
+5 \\
+6 \\
+7 \\
+8 \\
+9 \\
+10 \\
+11 \\
+12 \\
+13 \\
+14 \\
+15 \\
+16 \\
+17\end{array}$ & $\begin{array}{r}3.96 \\
2.42 \\
0.96 \\
0.72 \\
0.64 \\
1.26 \\
1.45 \\
1.76 \\
1.21 \\
1.39 \\
0.70 \\
0.56 \\
0.42 \\
0.68 \\
0.19 \\
0.20 \\
<0.13 \\
<0.13\end{array}$ & $\begin{array}{r}2.90 \\
8.50 \\
15.65 \\
34.35 \\
>50.00 \\
>50.00 \\
>50.00 \\
>50.00 \\
>50.00 \\
>50.00 \\
>50.00 \\
>50.00 \\
32.45 \\
22.25 \\
2.90 \\
1.60 \\
2.10 \\
<1.25\end{array}$ & $\begin{array}{r}2.5 \\
64.5 \\
54.4 \\
37.6 \\
25.9 \\
13.4 \\
9.1 \\
4.5 \\
3.8 \\
4.0 \\
3.6 \\
3.5 \\
3.2 \\
2.6 \\
3.1 \\
2.7 \\
3.3 \\
3.2\end{array}$ & $\begin{array}{r}<0.3 \\
<0.3 \\
<0.3 \\
<0.3 \\
<0.3 \\
<0.3 \\
<0.3 \\
<0.3 \\
<0.3 \\
<0.3 \\
<0.3 \\
<0.3 \\
0.56 \\
0.60 \\
0.74 \\
0.82 \\
0.60 \\
<0.3\end{array}$ \\
\hline
\end{tabular}

*Human chorionic gonadotrophin 5000 IU given intramuscularly.

tArtificial insemination from husband.

† Started to bleed heavily. $1 \mathrm{nmol} / \mathrm{l} \approx 0.3 \mathrm{ng} / \mathrm{ml}$.

\section{Comment}

We have no proof that fertilisation occurred, but the fact that two independent variables coincidentally indicated the possibility of conception, only after implantation could have occurred, makes fertilisation probable. The trend of Schwangerschaftsprotein 1 concentrations was quite different from that in our experience of normal pregnancy. ${ }^{2}$ In this patient the concentration fell or stayed level, whereas in normal pregnancy it rises steeply.

A widely accepted estimate puts the incidence of subclinical abortion at not less than $40 \%$ of potentially fertile cycles. ${ }^{5}$ Thus assay of Schwangerschaftsprotein 1 concentration may become a powerful tool in investigation of unexplained infertility.

We thank Dr F Dati of Behringwerke AG, Marburg, for the enzyme immunoassay kits and Miss Elaine Dalgarno for secretarial help. AGA is in receipt of funding from the University of Assiut, and $A K$ has a grant from the Wellcome Trust.

1 Edmonds DK, Lindsay KS, Miller JF, et al. Early embryonic mortality in women. Fertil Steril $1982 ; 38: 447-53$.

${ }^{2}$ Ahmed AG, Klopper A. The diagnosis of early pregnancy by assay of placental proteins. Br $\mathcal{F}$ Obstet Gynaecol (in press).

3 Abdulla U, Diver MJ, Hipkin LJ, et al. Plasma progesterone levels as an index of ovulation. Br $\mathcal{F}$ Obstet Gynaecol 1983;90:543-8.

4 Klopper A, Buchan P, Wilson G. The plasma half-life of placental hormones. Br $\mathcal{F}$ Obstet Gynaecol 1978;85:738-47.

5 Hertig AT, Rock J, Adams EC, Menkin MC. Thirty-four fertilized human ova, good, bad and indifferent, recovered from 210 women of known fertility. Pediatrics $1952 ; 23: 202$.

(Accepted 16 September 1983)

Department of Obstetrics and Gynaecology, Royal Infirmary, Aberdeen AB9 2ZB

A G AHMED, MB, PHD, clinical research assistant

A KLOPPER, PHD, MD, professor of reproductive endocrinology

Correspondence to: Professor A Klopper. 